\title{
What does the murder of a journalist, and follow-up events, tell us about freedom of the press and politics in a European country?
}

\author{
Andrej Školkay \\ ORCID: 0000-0002-8445-0580 \\ SCHOOL OF COMMUNICATION AND MEDIA, SLOVAKIA
}

DOI: 10.19195/1899-5101.12.1(22).2

\begin{abstract}
In February 2018, Slovakia's long history of the absence of journalist murder cases ended, when a young investigative journalist, Ján Kuciak, and his fiancée were murdered in their home. While previous cases of the disappearance of journalists cannot be totally dissociated from the possibilities of murder, a lack of evidence qualified this case as the first. The cascade of events which followed further emphasise its importance. Prime Minister Robert Fico was forced to resign. Resignations of the Minister of Culture, almost immediately, and two Ministers of the Interior followed. Subsequently, the third nominee for the position of Minister of the Interior was not approved by the President. These events were largely influenced by the media and public protests on the streets - some demonstrations were larger than those conducted during anti-communist protests in late 1989. Consequently, the role of the media as the key political actor following the murder of the journalist, represents an ideal model for analysing the influence of media in political and societal change.
\end{abstract}

KEYWORDS: Slovakia, murder, Kuciak, PSM, crisis, investigative journalism, state capture, grand corruption.

\section{INTRODUCTION}

Ján Kuciak, a young Slovak data investigative journalist and his fiancée, Martina Kušnírová, were murdered on February 21, 2018, in their home in Slovakia. This was the second case of the murder of an investigative journalist in the European Union (EU) in a year. The first involved a car explosion which killed Daphne Caruana Galizia, a Maltese journalist and blogger, whose investigations focused on political corruption in late 2017.

These two murder cases shared a few similarities. Firstly, it remains unclear who was behind them. It is worth mentioning that both governments invited foreign 
experts to help with the investigations into both murders. Secondly, each of the governments of the respective countries of the journalists, announced a one million euro reward for the provision of information which would facilitate the identification - and sentencing, for the Slovak case - of persons who were involved in the murder. ${ }^{1}$ Thirdly, the investigations of each of the murdered journalists, seemed to involve an underlying political factor: high-level political corruption. Daphne Caruana Galizia made repeated and detailed corruption allegations against the inner circle of Prime Minister Joseph Muscat. Similarly, Ján Kuciak's unfinished article, and the last before his demise, suggested connections between the local mafia and the inner circle of Prime Minister Robert Fico (see Kuciak, 2018). In both cases, the allegations were not proven. However, that is not enough to preclude the existence of political corruption. There are also important differences to note. The more direct and long-term politicised media framing of Galizia's investigative work, due to allegations she made, characterises a significant contrast between the Maltese case and its Slovak counterpart - even Prime Minister Muscat declared that Galizia was "his biggest adversary" (Pulse, 2017). The Slovak case was initially predominantly linked to an alleged local east Slovakian regional mafia-type network and its indirect connections to the government, but the identity of the possible perpetrators kept changing. The posthumous publishing of Kuciak's tentative investigative work provides a possible explanation for this pattern. Yet surprisingly, neither public protests nor political consequences in Malta reached intensities comparable to what was observed in Slovakia. Paradoxically, while Galizia could be seen as one of the most prominent journalists and bloggers in her country, Kuciak was virtually unknown. Inferentially, protests in Slovakia were independent of the journalist in question and possibly minimally related to his specific investigations. Instead, Kuciak's murder was seen as a symbolic event of special importance. The initial framing of the murder of Kuciak and the subsequent events related to selected media constitute the foremost issues to be discussed in this article in detail. The possible impact of both murders on EU common policies towards the protection of investigative journalists cannot be excluded. The changing paradigm of policies, especially of the EU parliament towards what was traditionally seen more or less as "cultural" and internal affairs of member states after the murder of journalists within the EU, deserves analytical attention, although it will not be discussed in detail in this article (see European Parliament, 2014-2019, 2018) Similarly, further detailed comparisons between the Slovak and Maltese cases will not be made here. Both issues deserve separate articles.

However, the alleged lack of freedom of public service media (PSM) or the Radio and Television of Slovakia (RTVS), and negative trends in this direction including the politicisation of PSM are worth discussing too. The framing of certain events and public statements as deep crises of PSM gained attention at home and

\footnotetext{
${ }^{1}$ Actually, the Slovak government was inspired here by the Maltese government.
} 
abroad soon after the double murder. As an example, the author of this article was approached by five foreign journalists who were interested in the freedom of the media in Slovakia in general, and in PSM in particular (see Školkay, 2018b). Kuciak, however, worked for a foreign-owned private news portal and not for PSM. Nevertheless, the politicisation of PSM was increasingly and explicitly presented in public-media discourse - especially by two liberal-right media (Denník N, Sme). Within this broader politico-criminal context, the dissatisfaction expressed by 59 journalists in PSM was wrongly and successfully framed by some media and public activists as a heroic revolt, against the ongoing and slow suppression of freedom of the media in PSM (see Prokopćák \& Krbatová, 2018). Additionally, this framing influenced many public figures and analysts who publicly supported clearly wrong narratives. Consequently, the ability of some analysts and public figures to offer an unbiased account of events remains in question and the wrong interpretation of ongoing trends may lead to unexpected consequences. Indeed, this framing supported by public outcry, even though not substantiated by facts, erupted into a full-blown crisis of PSM about two months after the murder and the director general of RTVS had to report the situation to the Permanent Committee for Culture and Media of the Slovak Parliament. Of course, the argument can be made that murder, as an ultimate suppression of critics and criticism, reveals trends which hitherto may have been suppressed before public eyes. This article argues that the framing of follow-up events in Slovakia presented by some key local and foreign media or journalists was wrong (see Školkay, 2018a).

The third issue notable for discussion is the causal relationship between the murder of Kuciak and the significant political changes which followed - this merges the two previous issues. Selected state authorities demonstrated increased responsiveness to claims of injustice and illegal activities, especially those concerning the office of the prosecutor general, when reported in the media. Long-term nationwide public protests in Slovakia following the double murder led to a government crisis, complicated by calls (supported by some media) for early parliamentary elections and the subsequent resignation of Prime Minister Robert Fico. Subsequent resignees included, among others, Robert Kaliňák, Tomáš Drucker, Tibor Gašpar and Marek Madarič - the Minister of the Interior, his replacement, President of the Police Force and the Minister of Culture respectively. Symbolic signalling of the politico-criminal background of the murder is further provided by the resignation of Robert Krajmer, Director of the National Anti-Corruption Unit of the National Criminal Agency, under media pressure to do so. Krajmer made an appearance at the crime scene, although there was no reason for him to do so.

The events are also perceived to have led to possible changes in the top management of PSM. While the link between Kuciak's murder and its dire political consequences is surprising, especially without evidence-based implications of the prime minister and the government, it is apparent that the media is a major catalyst for political change. Resignations which were not directly influenced by the media 
were driven by the huge wave of nationwide protests it ignited in one way or the other. The case of the minister of culture emphasises that there were selected selfinitiated resignations which were purely of a symbolic nature. Nevertheless, these events strengthen the argument that the media can substitute the state authorities - police, prosecutors, and courts - in their watchdog and supervisory activities. The murder was the final impetus which put together the various grievances from the public. Consequently, the media served as the channel to air these grievances and demands public, although certain elements were misleading - the media concurrently served as vigilant watchdog and the multiplier of public outcry. A minor section of the media and some journalists, however, moved further in their roles they became political actors on their own when they exaggerated a minor internal crisis within PSM. This minor conflict between professional and managerial values morphed into a scandal of nationwide proportions.

Although the actors behind the murder cases remain unknown (save for the killers themselves), it is obvious that the investigative work of journalists and bloggers can sometimes be seen by faulters - which may include politicians and other public figures - as a larger threat than the work of the police and other state authorities. This supported allegations of the involvement of politicians, public personalities, and government officials in the Kuciak case. Subsequently, public protests with the official buzzwords "For a decent Slovakia" became ultimate modalities for the explicit demand for a "fair" and "decent" state; a hoped-for deviation from what was currently seen as a "captured state".

Other issues caused national and international uproar. As an example, the approach Slovak police used to demand data from a Czech colleague of Kuciak - the temporary confiscation of her smartphone with the claim that data stored on it was needed for investigations - attracted international attention. Even though some foreign lawyers did not see this request as particularly unusual (see Kotalík, 2018) it was locally conspicuous in two ways - it was unfair at best, and was fuelled by a negative intention (see Jakubčo, 2018) to obtain contacts to protected sources of investigative journalists, at worst. The sensitivity of the media, public, and authorities to accusations, and their promptness in undertaking measures suggest that Slovakia became a "mediacracy" - the media enjoyed a significant influence on politics and state authorities. The perspectives and coverage of these events following the double murder justify the relevance of the story for a wider international audience.

\section{METHODOLOGY}

Various methodological approaches were employed for this study. Firstly, content analysis of the coverage of events following the double murder by selected media was conducted. The general focus was on the initial media framing of the murder of Kuciak and the analysis conducted by Tóth (2018) was utilised. It covered commentaries on journalistic texts published by the key media platforms and presented on 
Facebook - almost 50,000 commentaries covering eight days after the murder. Secondly, other media sources, including news portal aktuality.sk, conservative-Christian news portal postoj.sk, and the leftist news commentary portal noveslovo.sk were analysed. Kuciak worked for aktuality.sk, and the news-commentary portal noveslovo.sk was close to Smer-SD. The blog section of the newspaper Dennik N, which has most of its featured content from liberal-minded contributors, was also included for analysis. The selection of media sources and blogs was based on ideological orientation. In contrast with aktuality.sk and postoj.sk, noveslovo.sk demonstrated coverage which was solely focused on analyses and commentaries there was no left-wing leaning news portal in Slovakia. Analysis focused on content which covered the first four weeks subsequent to the police announcement of the murder - the reason for the murder and the actors behind it were key interests. Subsequently, the answers to key questions were categorised according to the analysed journal and blog contents, and a week-long analysis of the personalisation of events was done pending presentation. Thirdly, an analysis was conducted on what was perceived as the "politicisation of PSM", and sources of evidence were assessed to validate it. The assessment of the employment background of signatories of the public call which supported the allegation of journalist revolt in PSM, was key to conclusions made on this subject. Finally, the study researched an explanation for the causal relationship between the murder and the magnitude of political consequences which were observed. This analytical part was based on historical comparisons with similar events. Before engaging into case study analysis, some introduction into the theoretical context of media - politics relations, confronted with some empirical findings, might be useful.

\section{THE MEDIA AND POLITICS: A SHORT NORMATIVE THEORY AND VERY BASIC EMPIRICAL FINDINGS}

The normative theories of the media in a liberal democracy assume that free media should provide citizens with sufficient information and analyses, as well as freely and independently scrutinise holders of political power. There are a few specific roles associated with this public mission ("watchdog" role) according to arguably the most relevant and relatively recent key study on this topic by Christians, Glasser, McQuail, Nordenstreng and White (2009). It should be mentioned that the previous most cited summary of these roles or functions of the media go back half a century, although under slightly different keywords and concepts, in the 1956 classic Four Theories of the Press by Siebert, Peterson and Schramm (1956). In between, there were many studies that either "revisited" four theories or went "beyond" them.

Firstly, there is the Monitorial Role, that is, the process of observing an environment for relevant information about events, conditions, trends, and threats. Secondly, there is the Facilitative Role, when public opinion should arise from deliberation 
and is not antecedent to it. There is the Radical Role, when journalism makes every effort to ensure that no injustice is ever tolerated and there is an effort to eliminate concentrations of social power to enable every person to participate equally in social and political life. Finally, there is the Collaborative Role that implies a symbiotic relationship between media (including private media) and state authorities in times of emergency or need (Christians et al., 2009).

However, practically, there are often high expectations but low achievements. This discrepancy can be the result of external or internal factors, either at macro, mezzo or micro levels. For example, at the macro level, the role of free media in fighting corruption - identified arguably as one the most important factors detrimental to proper functioning of liberal democracies - differs depending on whether the country is considered a well, newly, or non-established electoral democracy. Consequently, the effect of press freedom on corruption starts off negatively or insignificantly for countries with very low levels of democracy, and becomes more positive the more democratic a country is (Färdigh et al., 2011). From this perspective, and considering the 2018 events, one can wonder how could one see Slovakia as a "consolidated" democracy (see Freedom House, 2018).

Be that as it may, at mezzo level, Sikorski's (2017) meta-review research, in particular, revealed that structurally, in relation to ownership structures, partisanship of a news organisation and the competitive context tend to influence news coverage about political scandals. In general, the media neglect most corruption, providing selectively too little, and not too much scandal coverage (Entman, 2012; Školkay \& Ištoková, 2016). Finally, at micro level, the collaborative role can turn into collusion among politicians and the media or a journalist (Školkay, 2016b).

Within this normative context, confronted with challenges journalists and the media face, it should be mentioned that there are arguments in favour of a new international instrument targeting the harassment of and violence against journalists (Draghici \& Woods, 2018).

The present study documents both positive achievements of an individual journalist (i.e., the successful monitorial roles of Kuciak at the micro-level), but also provides evidence of a failure of some media and journalists at the mezzo-level. This occurred when some media and some journalists turned their positive normative radical role into its negative extreme. This was the case of politicisation of internal conflict within PSM into a nationwide scandal on part of some media and journalists. If successful, this literary radical role could lead to unforeseen negative consequences for PSM and, possibly, indirectly, for the society at large. In effect, this could in all likelihood transpose into highly negative macro-level roles of the media and journalists. In other words, good intentions could turn into negative consequences. In fact, some nucleus negative tendencies of media coverage could be seen already in the initial framing of the murder of the journalist, attributing veracity to virtually all politically far-reaching claims in the posthumously published article by Kuciak. 
What does the murder of a journalist, and follow-up events, tell us about freedom of the press?

\section{WHAT WAS THE INITIAL FRAMING OF THE MURDER OF JÁN KUCIAK?}

The first data set (Tóth, 2018) showed the absence of a significant mention of "press freedom" or "PSM", and the dominance of the keywords "Fico", "Smer", and "mafia" - representing Robert Fico, his party, and the local mafia respectively — emphasised an indirect involvement of the government and the prime minister in the murder.

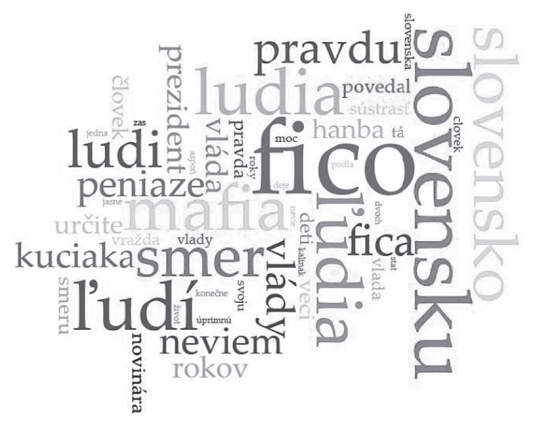

Figure 1. Commentaries on Facebook

Source: Tóth, 2018.

This argument is based on three observations. The first is based on allegations about suspicious contacts of some employees of the prime minister's office - Mária Trošková, officially identified as occupying the position of "public servant" and Viliam Jasaň, who served in the position of the secretary of the Security Council. These were based on Kuciak's last and unpublished writing, and presented by the media immediately after the murder. The second was based on Fico's harsh words towards journalists in the past. The final observation was made from a reflection on state authorities perceived to have been captured under the current government. The perceived absence of fair governance, or the presence of a "captured state", was seen as a major indirect threat for press freedom and journalism safety in Slovakia - the murder of Kuciak served as key evidence. An argument can be made to the effect that if authorities and politicians fulfilled their responsibilities, they would influence responsible conduct of stakeholders in better ways than the media (see Šebo, 2018). Concurrently, if authorities and politicians publicly provided the media with adequate support, journalists would be safer from criminal targeting. Until Kuciak's murder, authorities were perceived as slow and inefficient, with interests focused on covering up criminal activities of privileged elites. Intermittently, the media and journalists found actions by state authorities including prosecutors and the courts, and public statements by the sitting prime minister as a form of harassment.

The second figure is based on the content analysis of three media platforms, and supports the aforementioned arguments. The most mentions are attributed to the Prime Minister Roberto Fico, and the Minister of the Interior Robert Kaliňák, in 
Andrej Školkay

descending order. An unexpected rise for George Soros reflects a defensive strategy undertaken by the prime minister - his endeavour to link public protests to an international conspiracy.

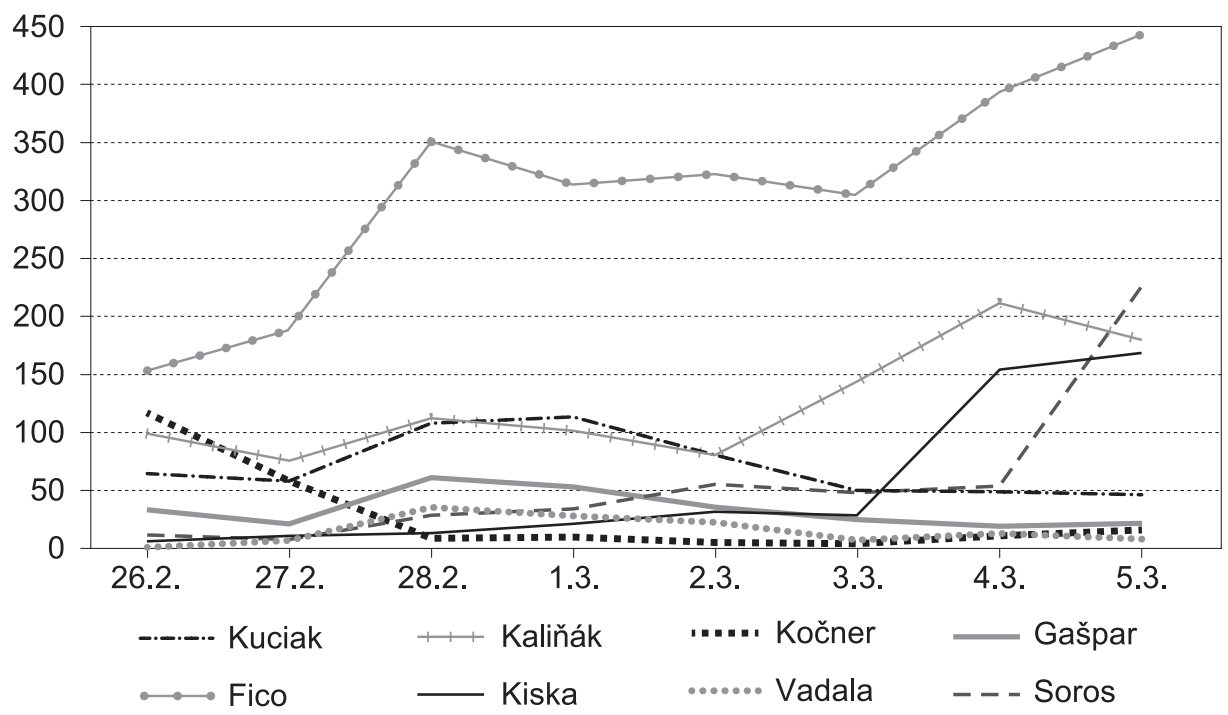

Figure 2. Persons mentioned in media reporting (in numbers)

Source: Author.

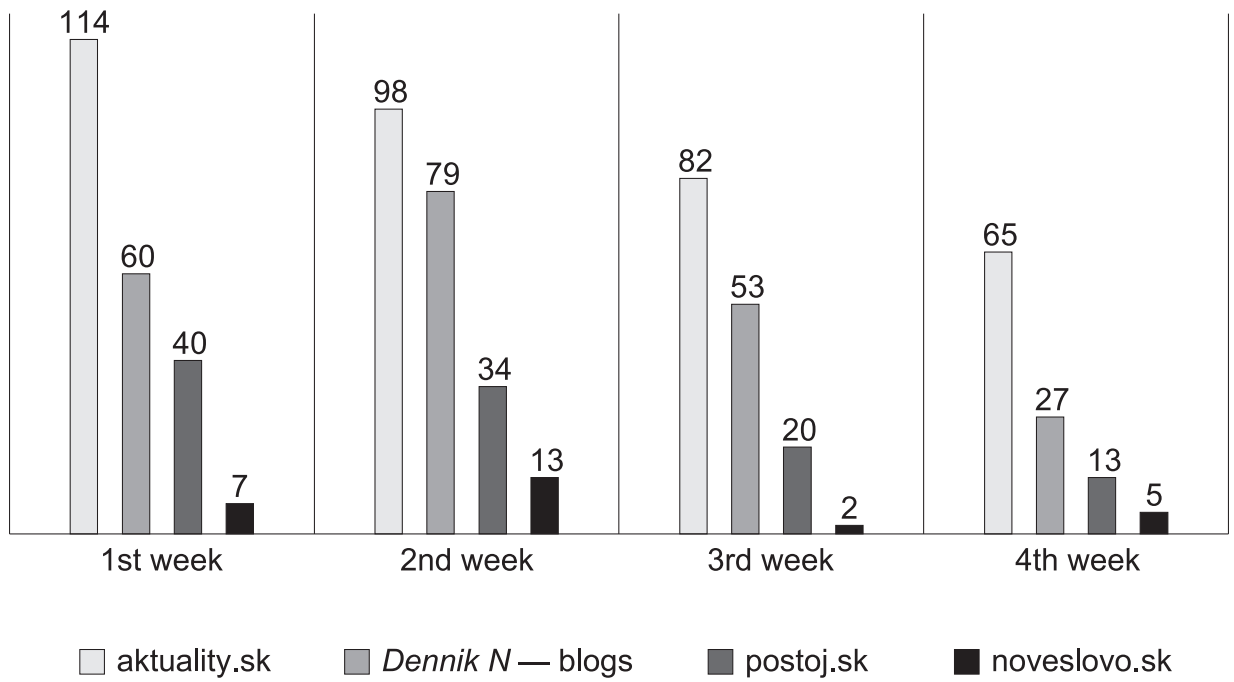

Figure 3. Number of articles

Source: Author. 
Analysis of the number of contributions from each of the sources of accessed content also revealed important patterns. The study found 359 articles from aktuality.sk, 107 articles from postoj.sk, 27 articles from noveslovo.sk, and 219 contributions from the blog section of daily Dennik $N$. The disparity between the contribution counts of noveslovo.sk and aktuality.sk, which recorded the lowest and highest number of contributions respectively, emphasise the politico-ideological connotations of the case. This is further supported by the slow decline in the number of journalistic contributions and the concurrent peak increase in commentaries in blog sections, during the second week after the murder.

The collection of reasons - or rather assumptions and opinions - for the occurrence of the murder constituted another important interest (Figure 4 and Table 1). In the majority of contributions, reasons for the murder were missing. This is not strange considering the dictates of news reporting - repetitions of news items are not favoured. Nevertheless, some deviations in coverage were noticed even within the limited sample of articles, which provided reasons or assumptions regarding what or who was behind the murder. The most notable uncertainty was attributed to insignificant mentions of the issue by noveslovo.sk. On the other hand, the conservative news portal and aktuality.sk were judged as the most opinionated, in descending order. These provided marginal narratives on the investigative work of Kuciak.

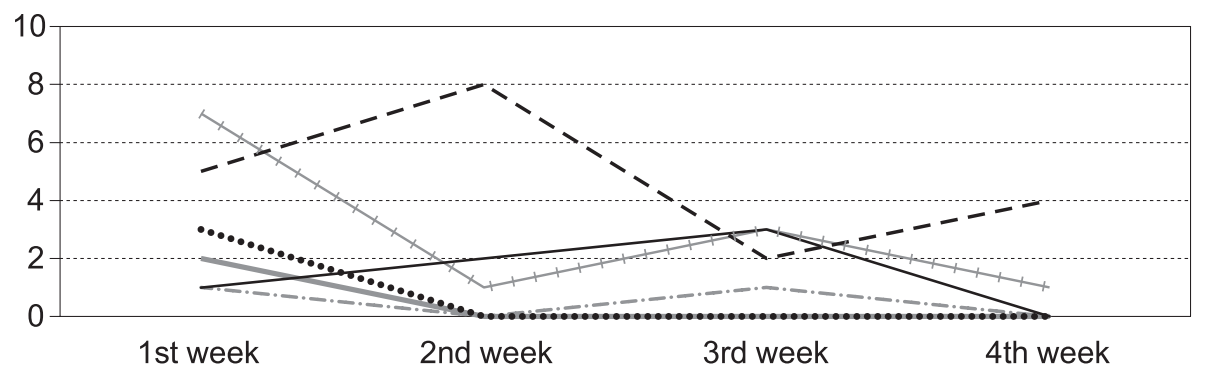

- government is to be blamed

criminal background

verbal attacks on the media by the PM

grand corruption with possible political links

- - - related to the investigative activity of a journalist

-.... other

Figure 4 . Why did this happen? Coverage by news portal aktuality.sk (in numbers)

Source: Author. 
Andrej Školkay

Table 1. Why did this happen? Uncertain/unknown opinions and the rest as presented by news portal aktuality.sk (in percent)

\begin{tabular}{|l|c|c|c|c|}
\hline \multicolumn{5}{|c|}{ Without the item uncertain/unknown opinion } \\
\hline & 1 st week & 2nd week & 3rd week & 4th week \\
\hline Uncertain/unknown opinion & $83.3 \%$ & $88.8 \%$ & $89.2 \%$ & $92.3 \%$ \\
\hline Remaining & $16.7 \%$ & $11.2 \%$ & $10.8 \%$ & $7.7 \%$ \\
\hline
\end{tabular}

Source: Author

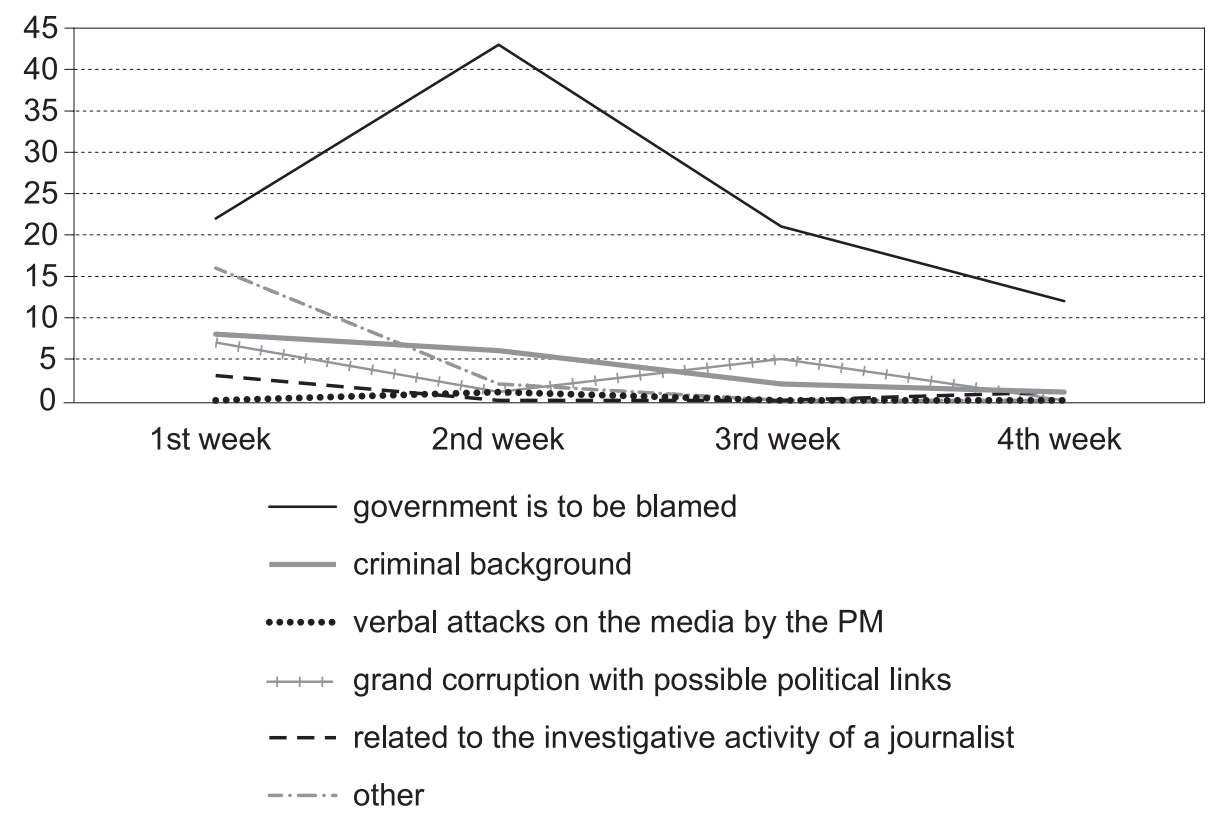

Figure 5. Why did this happen? Coverage by blogs at Dennik $N$ (in numbers)

Source: Author

Table 2. Why did this happen? Uncertain/unknown opinions and the rest as presented by blogs at Denník $N$ (in percent)

\begin{tabular}{|l|c|c|c|c|}
\hline \multicolumn{7}{|c|}{ Without the item uncertain/unknown opinion } \\
\hline & 1 st week & 2nd week & 3rd week & 4th week \\
\hline Uncertain/unknown opinion & $13.8 \%$ & $36.9 \%$ & $49.1 \%$ & $48.1 \%$ \\
\hline Remaining & $86.2 \%$ & $63.1 \%$ & $50.9 \%$ & $51.9 \%$ \\
\hline
\end{tabular}

Source: Author. 
What does the murder of a journalist, and follow-up events, tell us about freedom of the press?

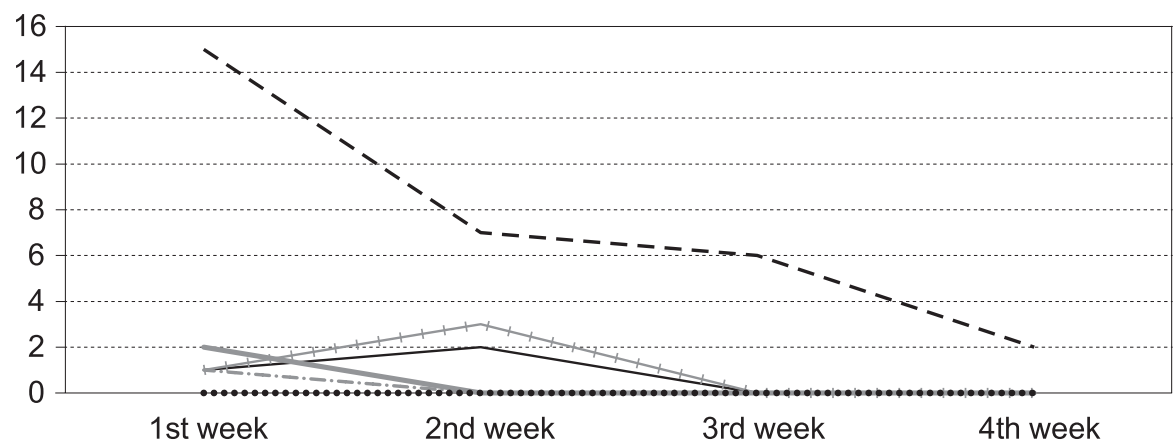

- government is to be blamed

— criminal background

....... verbal attacks on the media by the PM

$+1+$ grand corruption with possible political links

- - - related to the investigative activity of a journalist

-.-.. other

Figure 6. Why did this happen? Coverage by online daily postoj.sk (in numbers)

Source: Author.

Table 3. Why did this happen? Uncertain/unknown opinions and the rest as presented by online daily postoj.sk (in percent)

\begin{tabular}{|l|c|c|c|c|}
\hline \multicolumn{5}{|c|}{ Without the item uncertain/unknown opinion } \\
\hline & 1 1st week & 2nd week & 3rd week & 4th week \\
\hline Uncertain/unknown opinion & $54.5 \%$ & $68.4 \%$ & $70 \%$ & $84.6 \%$ \\
\hline Remaining & $45.5 \%$ & $31.6 \%$ & $30 \%$ & $15.4 \%$ \\
\hline
\end{tabular}

Source: Author.

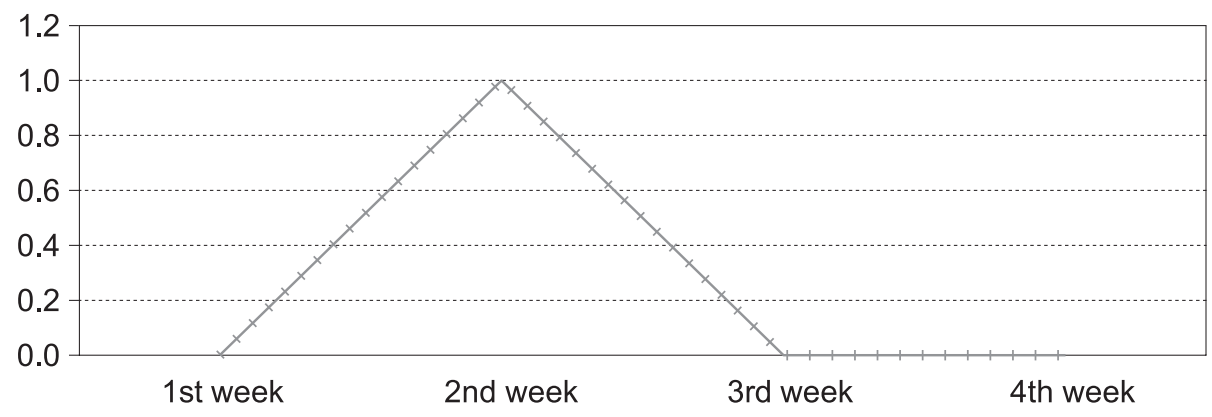

grand corruption with possible political links

Figure 7. Why did this happen? Coverage by leftist portal noveslovo.sk (in numbers)

Source: Author. 
Table 4. Why did this happen? Uncertain/unknown opinions and the rest as presented by leftist portal noveslovo.sk (in percent)

\begin{tabular}{|l|c|c|c|c|}
\hline \multicolumn{5}{|c|}{ Without the item uncertain/unknown opinion } \\
\hline & 1 st week & 2nd week & 3rd week & 4th week \\
\hline Uncertain/unknown opinion & $100 \%$ & $92.3 \%$ & $100 \%$ & $100 \%$ \\
\hline Remaining & $0 \%$ & $7.7 \%$ & $0 \%$ & $0 \%$ \\
\hline
\end{tabular}

Source: Author.

\section{WHY WAS THERE A CRISIS IN PSM?}

Now we turn to the issue of the crisis in PSM, which illustrates how a misleading interpretation of facts may lead to a full-blown institutional crisis. Such a crisis, based on wrong claims, can occur under normal circumstances even though it is obviously more likely to happen under emotionally stressful nationwide or near-emergency situations. Although there were two contradicting explanations available on the crisis of PSM, the more radical and misleading tended to influence politicians to a larger extent. The first explanation supported the hypothetical politicisation of PSM in Slovakia (see SME Domov, 2018). In contrast, the second explanation related it to the change of management and the routine alignment of the operations of the institution with its legitimate and legal policies. Both groups argued that they work under free conditions, although in certain ways, conflict evolved into extreme and public dimensions. Within this context, three active opinion groups become visibly involved in the process which shaped the public discourse. The most vocal group, unofficially led by 29 -year-old Zuzana Kovačič-Hanzelová, consisted of about 300 loosely-connected non-journalists and journalists out of an estimated count of more than 3,000 and up to 5,000 journalists in Slovakia ${ }^{2}$ (see interview in Mikušovič, 2018b). They included 200 journalists from other media who supported revolting PSM journalists (Viac ako 170..., 2018), 59 journalists and reporters from PSM and 50 literary journalists and technical employees of PSM who were keen on demanding fair treatment in support of their colleagues - they also emphasised the non-existence of negative labour or editorial relations in their work (V RTVS zverejnili..., 2018). The second included a group of 40 PSM journalists who refuted all claims of politicisation of PSM, and the signatories included Tibor Macák, General Secretary of the Association of European Journalists (Ďalši otvorený list..., 2018). This group can be regarded as comprising of a majority of "silent" journalists who did not support the revolting journalists. Under the exceptional circumstances which followed the murder of their colleague, they certainly would not be afraid

2 There is no official definition of a journalist - practically anyone can become or claim to be a journalist. 
to speak and protest openly. In fact, some of them spoke, but clearly refuted politicisation of PSM and further questioned the motivation and professionalism of the revolting journalists (see Múcka \& Hanus, 2018). The third group included public intellectuals and activists, sometimes representing institutions, who issued various statements in support of the first group (Vyhlásenie Fakulty masmédií..., 2018; Vyhlásenie Filozofickej fakulty..., 2018; Vyhlásenie pedagógov Vysokej..., 2018).

Figure 8 demonstrates an important pattern. Out of more than 200 journalists who signed the petition supporting 59 PSM journalists, almost half came from two liberal-right newspapers - Sme (We Are) and Denník N (Newspaper N). Although these are among the most reputable, critical, and agile journalists in Slovakia, they are predominantly liberals living in their "bubbles" and have a tendency of assessing cases in an unconventional radico-libertarian way which might not align with reality. Additionally, the lack of a majority support for their call raises a red flag.

Findings from the detailed analysis of PSM staff contradict the notion that a significant number were involved in the alleged revolt. The number of protestors out of 1,450 full-time employees including 250 reporters, and an additionally estimated 1,500 part-time employees and contractual co-workers, was found to be low. Some of the grievances listed in the initial letter are worth mentioning. The first was about distrust towards mid-level management - particularly three senior editors who had previously worked at various governmental press departments. The second was about the lack of a mechanism to prevent possible conflict of interest in coverage cases of journalists being sacked, demoted or transferred after they had expressed critical views towards the management. The third was about pressure from management to balance news reports with opinions of persons known to lack expertise, breed disinformation, or entertain political ambitions. Nonetheless, the letter explicitly mentioned - rather paradoxically - that signatories worked under free conditions. An article published in Dennik N, one of the two liberal newspapers at the peak of the crisis, admitted that there was not a single case of political intervention from top management of PSM since a new director-general had been elected in the previous year (Mikušovič, 2018a). This alternative explanation was supported by a second group of 40 equally respected journalists, reporters, and anchors who worked at PSM. As previously mentioned, they issued a counterstatement refuting the claims made by the initial letter. There is also a case to be made that if the allegations of politicisation were in fact true, more than 300 journalists would be willing to provide their endorsement.

According to findings from a survey carried out between June 28 and July 5 , 2018 (i.e., a month after the peak of crisis in PSM), a representation of $63.7 \%$ of over 1,000 respondents trusted PSM. In contrast, private media were trusted by only $42.6 \%$ of respondents (TASR, 2018). Consequently, if there was a highly politicised PSM broadcast, it is very likely that the public would have noticed differences. In fact, the opposite seemed to be the case. A more realistic presentation of the conflict, which was framed as a press freedom issue by some public or professional 


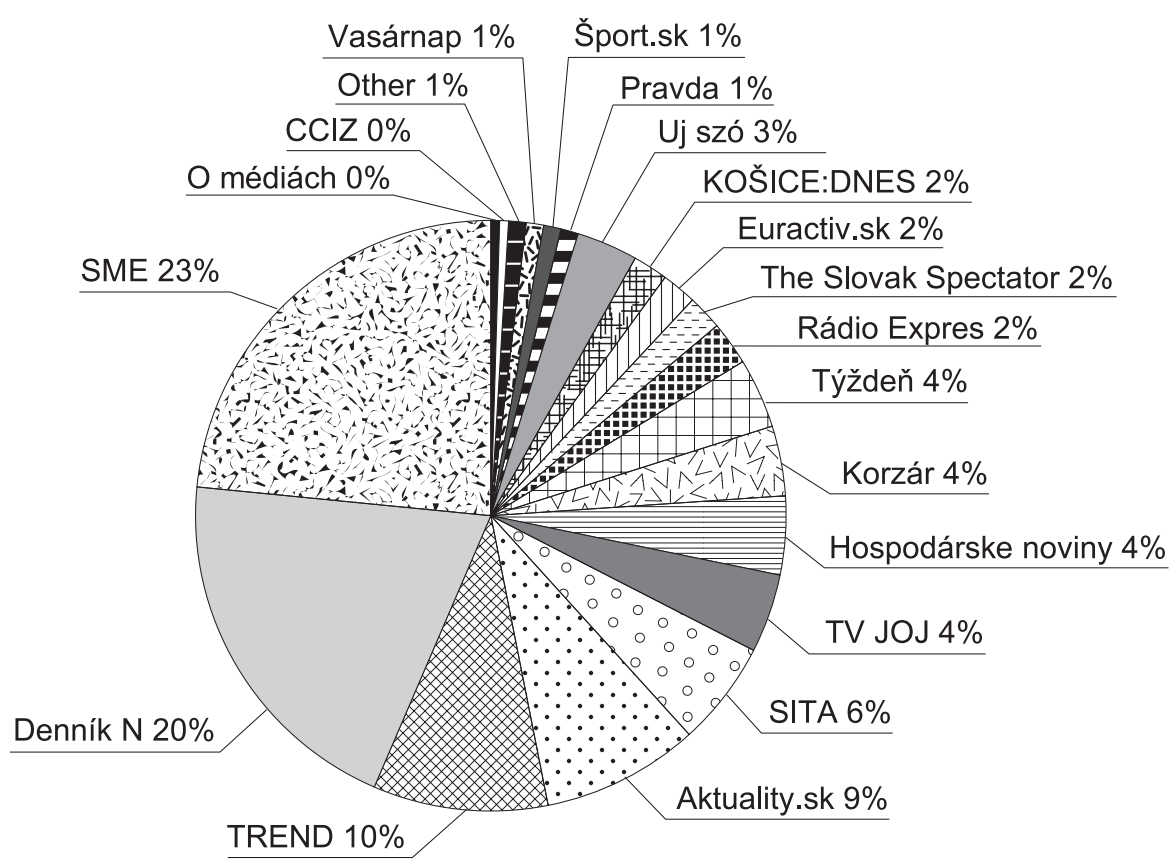

Figure 8. Employment analysis of supporters of an open letter in favour of revolting journalists in PSM (in percent)

Source: Author.

voices, was concerned with the professional and managerial norms regarding who was meant to run public media, and what its "public service mission" was meant to be. This was complicated by the characteristic dominance of liberal and centre-right opinions, from the most vocal among the best print media journalists in Slovakia. They demonstrated long-term anti-Fico tendencies, especially with the negativity their coverage portrayed towards him (Školkay, 2016a). This has been linked to historical issues relating to the communist past and post-communist political transition in Slovakia. Obviously, some of those critical voices aimed at PSM did not recognise certain previous ethical failures of their colleagues (see Školkay, 2016c). The third group, comprising prominent advocates and voices supporting press freedom in Slovakia, included the Faculty for Mass Media of the Pan-European University, the Faculty of the Arts at Comenius University, a watchdog portal known as omediach.com, and selected politicians in the opposition. Notwithstanding, prominent advocates for press freedom are not always able to understand the actual background of ongoing events and differentiate between important issues. Consequently, their support may be misguided and result in failure, as was evident in this case. 
What does the murder of a journalist, and follow-up events, tell us about freedom of the press?

\section{WHY DID THE MURDER OF A JOURNALIST LEAD TO POLITICAL CONSEQUENCES?}

It is not a coincidence that Slovak news portals collectively reported 1.53 million of "daily unique real users (RU) visitors" on Monday, March 12, 2018. This day marks the resignation announcement of Robert Kaliňák, the Minister of the Interior. The previous record for the highest internet traffic, 1.429 million RU, occurred a day after parliamentary elections in March 2016 (MediaBrifing, 2018). This suggests that the news about the resignation of the minister of the interior was of paramount importance for the public at large - inferentially, it was more important than the results of parliamentary elections. The heightened interest towards the resignation of the Minister of the Interior and other political sequelae of the murder, raises critical questions. It is notable that in the last 50 years of Slovakia - including the period of being part of Czechoslovakia - there has been a seemingly recurring sociological pattern. A major social upheaval was facilitated by what was seen as a "political" murder, irrespective of whether it was alleged or not, within the period of a new generation. Similarly, co-operation among social and political groups or individuals, hitherto isolated, was facilitated by the same events and perception which governed the argument that state authorities, including courts, prosecutors, and police, were politicised or captured. Havel (1990, pp. 51-52) explained that the turning point for the dissident movement in erstwhile Czechoslovakia was a court case with The Plastic People of the Universe, a music band, in early 1976. This political court case led to the establishment of cooperation among various opposing groups. There was also international support, in the form of an international human rights covenant signed in Helsinki by the communist government, a few months earlier. Havel also indicated that a similar situation happened in Czechoslovakia in the 1950s. He pointed out that in both cases, there were new generations that grew up under a new regime and entered a confrontation with it. In the former case relating to the music band, new actors realised that a legal action against young and unknown musicians, was a substitute act. In other words, it was an act which could happen to everyone. Interestingly, even the Velvet Revolution in 1989 got its impetus from the public uproar over the alleged death of a student during a demonstration in Prague on November 17, 1989. Similarly, the isolated dissident groups in Slovakia consented to closer contact and better co-operation, only after the court case with five dissidents in Slovakia in the autumn of 1989, and its related public events (Antalová, 1999). Here too, the international context - period of Glasnost and Perestrojka in the erstwhile Soviet Union, as well as events in neighbouring communist countries - was an important factor. From this historical perspective, the murder of Kuciak can be placed in the same category of turning-point events in Slovak history. There was a new generation which was actively organising follow-up protests in response to the allegations of the capture of state authorities, and Kuciak's murder served as a unifying moment for all other disappointed protest voices against the government. The international environment was also supporting positive intervention. This time there were various European institutions that were providing support 
for independent media and civil society actors. There were many public protests in the previous year demanding adequate investigation of the dubious business activities of some persons. Although these implicated the prime minister and minister of the interior, they did not yield any recognisable results. Evidently, Kuciak's murder was the catalyst for the large wave of political changes and higher sensitivity of authorities towards claims of wrongdoing.

\section{CONCLUSION}

The murder of Kuciak resulted in a black-swan phenomenon in Slovakia - no one expected it, but it facilitated important and swift political changes in the country. At the moment of writing, a "mediacracy" has emerged. The media, including social media, has become a significant influence on the public and political agenda as a result of the assassination of Ján Kuciak and his fiancée. This "mediacracy" was largely facilitated by public protests - these collectively represent an unprecedented magnitude in the 25 -year history of post-independence Slovakia. While media and journalists can create and contribute to exaggerated and unsubstantiated scandals such as the case with PSM, the positive outcomes subsequent to media efforts in pushing authorities to act, and in given cases forcing politicians and other suspected prominent actors to resign, is commendable. These endeavours of the media and journalists may help to correct some excesses - including the rather slow responsiveness, reluctant approaches of public authorities in some cases, and attempts to suppress cases of cronyism and corruption present in politics. However, checks for objectivity and vigilance must be instituted to mitigate purposeless, counterproductive, or false criticism - an absence of such checks may be counter-intuitive and facilitate outcomes which otherwise must be prevented. Inferentially, an argument can be made in favour of a reversed politicisation of the media in Slovakia - the media and some journalists de facto became political actors. This represents an unusual deviation from the situation in neighbouring Poland or Hungary, although the opposite is perceived by some observers. Clearly, this was also a deviation from normative theories too - although perhaps justified, or understandable by specific conditions after the murder of a journalist, and within the general context of a partially captured state.

Moreover, different interpretations of an event can be made depending on who provides a report. Clearly, there is no guarantee that explanations for an event from Slovakia's most reputable and renowned journalists, academicians, and civil society activists will always be factual. This questions the veracity of journalistic and even academic articles based on interviews. Furthermore, media coverage of the same event may be rather diverse. Indeed, journalism has only been considered as the first draft of history - usually, journalism does not have a strong impact on politics. The tragic death of Kuciak and the resultant change in the course of history sets the foundation for a realisation of the larger, but exceptional, and most likely only a temporary influence of the media on political and societal change. 
What does the murder of a journalist, and follow-up events, tell us about freedom of the press?

\section{REFERENCES}

Antalová, I. (1999). Verejnost' proti násiliu. Občianske fórum [The public against violence. Civic forum]. Bratislava: Nadácia Milana Šimečku.

Christians, C., Glasser, T., McQuail, D., Nordenstreng, K., \& White, R. (2009). Normative Theories of the Media: Journalism in Democratic Societies. Illinois: University of Illinois Press.

Ďalši otvorený list z RTVS: Nikto na nás nevyvija nátlak [Another open letter from RTVS. No one is putting any pressure on us]. (2018). Retrieved April 13, 2018 from https://www.omediach.com/ tv/13003-dalsi-otvoreny-list-z-rtvs-nikto-na-nas-nevyvija-natlak.

Draghici, C., \& Woods, L. M. (2018). Killing journalists is not media regulation: Private rights, collective wrongs and the impact of impunity. Journal of Transnational Law and Contemporary Problems, forthcoming.

Entman, R. M. (2012). Scandal and Silence: Media Responses to Presidential Misconduct. Cambridge, Oxford, Boston: Polity.

European Parliament, 2014-2019 (2018). Committee on Civil Liberties, Justice and Home Affairs, MISSION REPORT, following the Ad - hoc delegation to Slovakia and Malta 17-20 September 2018. Retrieved November 16, 2018 from http://www.europarl.europa.eu/meetdocs/2014_2019/plmrep/ COMMITTEES/LIBE/DV/2018/11-19/1169408EN.pdf.

Färdigh, M. A., Andersson, E., \& Oscarsson, H. (2011). Re-examining the relationship between press freedom and corruption. QoG Working Paper Series, 13, pp. 1-32.

Freedom House (2018). Nations in Transit 2018. Retrieved July 7, 2018 from https://freedomhouse. org/ report/nations-transit/2018/slovakia.

Havel, V. (1990). O lidskou identitu [On human identity]. Prague: Rozmluvy.

Jakubčo, J. (2018). Vyhlásenie vydavatelov a šéfredaktorov: Polícia musí vysvetlit svoj postup voči Holcovej. Polícia zobrala novinárke mobil [Statement by publishers and editors-in-chief: The police must explain its approach towards Holcová]. Retrieved May 16, 2018 from https://komentare.sme. sk/c/20827322/vyhlasenie-vydavatelov-a-sefredaktorov-policia-musi-vysvetlit-svoj-postup-vociholcovej.html\#ixzz5ML 23SZXg.

Kotalík, J. (2018). I po svědkovi může chtít policie telefon, stává se to, ř́ká advokát [The police can ask a witness to provide his smartphone, this is nothing unusual, says a lawyer]. Retrieved May 20, 2018 from https://zpravy.idnes.cz/policie-vyslech-odebrani-mobilu-holcova-kuciak-advokati-p2s-/kri mi.aspx?c=A180518_104437_krimi_jkk.

Kuciak, J. (2018). Talianska mafia na Slovensku. Jej chápadlá siahajú aj do politiky [Italian mafia in Slovakia. It is connected to politics]. Retrieved February 28, 2018 from https://www. aktuality.sk/ clanok/568007/talianska-mafia-na-slovensku-jej-chapadla-siahaju-aj-do-politiky/y.

MediaBrifing (2018). Týždňový newsletter Filipa Struhárika o médiách a žurnalistike [Weekly newsletter by Filip Struhárik on media and journalism]. Retrieved April 6, 2018 via mailing list from https:// dennikn.sk/1086874/spravodajske-media-dosiahli-v-marci-rekordy-hlavne-spravy-maju-citanosttakmer-na-urovni-ta3/?ref=tema.

Mikušovič, D. (2018a). Hlavne vyvažujme: O čo vlastne ide v RTVS a prečo reportéri v televízii začínajú hovorit o autocenzúre [We should provide balanced coverage: What is the issue in RTVS and why reporters in television broadcasting started to talk about self-censorship], Denník N. Retrieved May 6, 2018 from https://dennikn.sk/1112906/hlavne-vyvazujme-o-co-vlastne-ide-v-rtvs-a-precoreporteri-v-televizii-zacinaju-hovorit-o-autocenzure/?ref=list.

Mikušovič, D. (2018b). Zuzana Kovačič Hanzelová: Dúfala som, že vydržím dlhšie [Zuzana KovačičHanzelová: I hoped to survive a bit longer], Denník N. Retrieved June 1, 2018 from https://dennikn. sk/1138873/zuzana-kovacic-hanzelova-dufala-som-ze-vydrzim-dlhsie/.

Múčka, F., \& Hanus, M. (2018). Rozvrat [Disruption]. Retrieved May 2, 2018 from https://www.postoj. sk/32865/rozvrat. 
Prokopcák, T., \& Krbatová, L. (2018). Pokojne to volajme otvorená vojna. Alebo normalizácia, to bude ešte lepší výraz [We can name it open war. Or normalisation, this would be an even better term] Retrieved April 29, 2018 from https://domov.sme.sk/c/20814284/podcast-v-rtvs-zuri-vojna-reznikvyhadzuje-ludi.html.

Pulse (2017). Malta PM says slain blogger was his 'biggest adversary' but vows justice. Retrieved October 18, 2017 from https://www.pulse.ng/news/world/joseph-muscat-malta-pm-says -slain-blogger-was-his-biggest-adversary-but-vows-justice/jx714cl.

Šebo, E. (2018). „Bitka o ministerstvo vnútra” a jej dôsledky pre Smer ["Battle for the Ministry of the Interior" and its consequences for Smer]. Retrieved May 4, 2018 from https://blog.postoj.sk/32944/ bitka-o-ministerstvo-vnutra-a-jej-dosledky-pre-smer.

Siebert, F., Peterson T., \& Schramm W. (1956). Four Theories of the Press: The Authoritarian, Libertarian, Social Responsibility, and Soviet Communist Concepts of What the Press Should Be and Do. Champaign, IL: University of Illinois Press.

Sikorski, C. von (2017). Politische Skandalberichterstattung: ein Forschungsüberblick und Systematisierungsversuch. Publizistik, 62(3), pp. 299-323.

Školkay, A. (2016a). Computer-Assisted Content Analysis of the print press coverage of corruption in Slovakia. Retrieved June 5, 2018 from http://anticorrp.eu/publication_type/deliverable/.

Školkay, A. (2016b). Collusion between politicians and journalists in the context of wiretapping of journalists. Środkowoeuropejskie Studia Polityczne, 2, pp. 107-124.

Školkay, A. (2016c). Media Landscapes, Slovakia - Accountability Systems. Retrieved April 22, 2018 from https://medialandscapes.org/country/slovakia/policies/accountability-systems.

Školkay, A., \& Ištoková, A. (2016). Media coverage of corruption: The role of inter-media agenda setting in the context of media reporting on scandals. Srodkowoeuropejskie Studia Polityczne, 2, pp. 125-140.

Školkay, A. (2018a). Čo zaujíma zahraničie ohladom smrti investigatívneho novinára [What are foreigners interested in regarding the murder of an investigative journalist]. Retrieved March 8, 2018 from https://dennikn.sk/blog/1048143/co-zaujima-zahranicie-ohladom-smrti-investigativn eho-novinara/.

Školkay, A. (2018b). Podtyp fake news - emocionálna dezinterpretácia vybraných udalostí ( $k$ dianiu $v$ RTVS) [Sub-type of fake news - emotional misinterpretation of selected events in RTVS]. Retrieved May 14, 2018 from https://dennikn.sk/blog/1122466/podtyp-fakenews-emocionalna-dezinterpetacia-vybranych-udalosti-k-dianiu-v-rtvs/.

SME Domov (2018). Otvorený list členov Sekcie spravodajstva a publicistiky RTVS (plné znenie). [Open letter to members of the Department of News and Current Affairs of RTVS (the full text)]. Retrieved April 4, 2018 from https://domov.sme.sk/c/20795636/otvoreny-list-clenov-sekcie-spravodajstva-apublicistiky-rtvs-plne-znenie-reznik.html.

TASR (2018). Najôveryhodnejšou inštitúciou na Slovensku je SAV, ukázal prieskum [The most trusted institution in Slovakia is the Academy of Sciences]. Retrieved July 19, 2018 from https://spravy.pravda. sk/domace/clanok/477437-najdoveryhodnejsou-instituciou-na-slovensku-je-sav-tvrdi-focus/.

Tóth, G. (2018). Hlavnou postavou v kauze vraždy novinára je od začiatku Fico [The key person in the murder case of a journalist has been Fico from the beginning]. Retrieved March 3, 2018 from https:// blog.etrend.sk/gabriel-toth/hlavnou-postavou-v-kauze-vrazdy-novinara-je-od-zaciatku-fico.html.

$V$ RTVS zverejnili d’alší otvorený list, tentokrát ludia mimo spravodajstva [There has been published another open letter, this time by people outside of the news department] (2018). Retrieved May 4, 2018 from https://www.omediach.com/tv/13165-v-rtvs-zverejnili-dalsi-otvoreny-listtentokrat-ludia-mimo-spravodajstva.

Viac ako 170 novinárov podporilo kolegov $z$ RTVS: Verejnoprávne médiá nemožno umlčat' [More than 170 journalists showed support for their colleagues in RTVS: PSM should not be silenced] (2018). Retrieved May 3, 2018 from https://www.omediach.com/tv/13152-viac-ako-170-novinarov-podporilo-kolegov-z-rtvs-ani-verejnopravne-media-nemozno-umlcat. 
What does the murder of a journalist, and follow-up events, tell us about freedom of the press?

Vyhlásenie Fakulty masmédií PEVŠ k situácii v RTVS [Statement of the Faculty of the Media of PanEuropean University] (2018). Retrieved May 4, 2018 from https://www.omediach.com/strucne/ 13164-vyhlasenie-fakulty-masmedii-pevs-k-situacii-v-rtv.

Vyhlásenie Filozofickej fakulty UK $k$ dianiu $v$ RTVS. [Statement of the Faculty of Arts of Comenius University] (2018). Retrieved April 30, 2018 from https://www.omediach.com/ tv/13129-vyhlasenie-filozofickej-fakulty-uk-k-dianiu-v-rtvs.

Vyhlásenie pedagógov Vysokej školy múzických umení k situácii v RTVS [Statement of lecturers of the College of Arts on the situation in RTV] (2018). Retrieved May 6, 2018 from https://www.omediach.com/ tlacove-spravy/13167-vyhlasenie-pedagogov-vysokej-skoly-muzic kych- umeni-k-situacii-v-rtvs.

Telephone interview with Tomáš Mrva, RTVS online editor (signatory of an open letter), June 28, 2018. 